
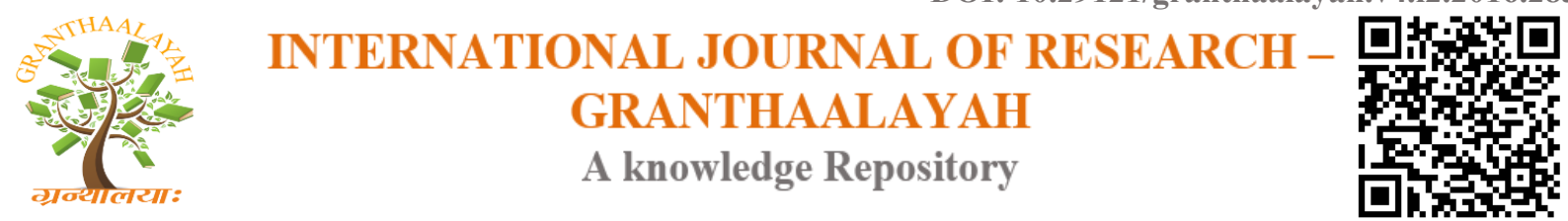

Management

\title{
A STUDY OF THE ATTITUDE OF CUSTOMERS AND AGENTS TOWARDS THE PROPOSED INCREASE OF FDI IN THE INSURANCE SECTOR IN CHENNAI METROPOLIS
}

\author{
Venkataramani.K $^{* 1}$, Dr. R. Mohan Kumar ${ }^{2}$, Dr. G. Brindha ${ }^{3}$ \\ ${ }^{* 1}$ Research Scholar, Management Studies,Bharath University, Chennai, INDIA \\ ${ }^{2}$ Professor \& HOD, Department of Management Studies, Sri Krishna Engineering College, \\ Chennai, INDIA \\ ${ }^{3}$ Professor, Department of Management Studies, Bharath University.Chennai, INDIA
}

\begin{abstract}
This paper describes a study of the attitude of Chennai based consumers and agents towards the proposed increase in Foreign Direct Investment (FDI). The study focuses on the impact of FDI in insurance as perceived by both the customers and agents in terms of viability, service, benefits, and overall benefits vis-a-vis existing scene. A quantitative survey was conducted with a special measuring tool specifically devised for this study. The sample group consisted of Chennai based insurance customers and agents. The results indicated that the customers welcomed the increase in FDI for they perceived better and quicker service, better options, and professionalism in insurance transactions.
\end{abstract}

Keywords:

FDI, insurance, perception, Chennai Metropolis.

Cite This Article: Venkataramani.K, Dr. R. Mohan Kumar, and Dr. G. Brindha, “A STUDY OF THE ATTITUDE OF CUSTOMERS AND AGENTS TOWARDS THE PROPOSED INCREASE OF FDI IN THE INSURANCE SECTOR IN CHENNAI METROPOLIS" International Journal of Research - Granthaalayah, Vol. 4, No. 2 (2016): 250-257.

\section{INTRODUCTION}

\section{HISTORY OF INDIAN INSURANCE INDUSTRY}

Indian Insurance industry dates back to 1818 when the first life insurance company, The Oriental Life Insurance Company was set up in Calcutta (now Kolkata) basically to cater to the needs of the European community. The enactment of the British Insurance Act in 1870 paved the way for foreign insurance companies in India. With many companies in the field, The Indian Life Assurance Companies Act in 1912 was considered the first measure to regulate business in the insurance sector. After the enactment of Indian Insurance Companies Act in 1928, statistical data both in life and non-life insurance began to be collected by the government. Then, to protect the 
insurance public and to make provisions for effective control, the Government Insurance Act was passed in 1938.

The Government of Indian then, in 1956, issued an ordinance, nationalizing all the existing insurance companies, then, in all 154 Indian and 16 foreign companies. It then set up its own body, the Life Insurance Company (LIC) of Indian which went to monopolize the insurance market till 1990. In 1993, the Malhotra Committee published startling revelations about the insurance scene in India. It argued that only $22 \%$ of the population of India was insured and made recommendation to open the market to private players. In 1999, an autonomous body, The Insurance Regulatory and Development Authority (IRDA)was formed to regulate and develop the insurance industry.

In 2000, the government of India took a landmark decision to open the insurance industry to private sector and allowed foreign equity participation to an extent of $26 \%$ of the paid-up capital. There are today 46 private companies and 8 public sector units in the insurance industry in India. In almost all the private companies there is a foreign investment of $26 \%$ of the paid-up capital. According to reports, the market is still big with only.

\section{STATEMENT OF THE PROBLEM}

In 2008, the Insurance Amendment Bill to raise foreign equity participation from $26 \%$ to $49 \%$ was tabled in the upper house (the Rajya Sabha) of the parliament. The issue has been pending since then and when the new government assume office, the interest has been revived. Therefore, this study is appropriate and timely, and can provide valuable insights to policy makers and entrepreneurs, particularly in metropolises of India where the market for insurance products is huge.

\section{OBJECTIVES OF THE STUDY}

The major objectives of the study are listed below:

- To measure the impact of increased FDI by the public and insurance agents in the metropolis of Chennai.

- To analyze how increased FDI would impact service as perceived by customers and insurance agents in Chennai.

- To study the perceived general benefits of rise in FDI

- To analyze the perceived impact on the economy in general.

- To study the attitude and difference in it if any, of the people of the metropolis to such a rise in FDI in the insurance sector.

\section{REVIEW OF LITERATURE}

In this section a review of literature on FDI in insurance industry in India is presented, highlighting the views, opinions, suggestions and recommendations made by experts in the field in articles, papers and journals. According to Vijaya Kumar (2004) the opening up of the insurance sector to FDI has fostered completion, innovation and product variations. According to 
Mr Kumar, insurance products issues such as pension plans, delinking banking from insurance, digitizing products and services and using the Indian Postal network and the need for a regulatory body are points that need to be addressed urgently.

Murthy (2004) has argued that the raising the cap from $26 \%$ to $49 \%$ will fulfil the need for the much needed capital that the industry has been facing with growing business potential. It will also give a competitive edge to players in vying with the so far monopolized industry.

Krishna Kumar and Kannan (2005) have studied the impact of the entry of private sector in the industry and the position of the LIC in the insurance sector. They have highlighted the threats that the giants could face and possible steps to be adopted to stay healthy in business. The study also provides useful analytical tools.

Sayalu and Sardar (2005) have suggested that product value and customer satisfaction are important ingredients for the success of insurance companies in the market. They would greatly help in the bonding between customers and companies whose relationship extend over a great period of time. They would also arrest defection rate in business.

Sam Ghosh (2005) has acknowledged that the scene in the insurance market in India has greatly changed. The private players have changed the rules of the game by expanding the range of products, pricing and delivery of service.

Niraj Maumdar (2005) lauds the private players and notes that the private players have made inroads into the market of the monolith of Indian insurance, the LIC of India, by capturing $25 \%$ of the market share of the insurance products.

Bansal (2005) argues that the private players have impacted the market positively and this positive mood has been consistent over a period of time. He opines that private sector have a great deal of potential and will the take the industry a long way from here.

Pooja Bhallia and Gangadeep Kaur (2005) have posited that the entry of private players have certainly posed a threat to the industry giant, the LIC of India. Though it is still the major player in insurance, it is losing its ground year by year. The private players with their innovative products, better service and aggressive branding have been able to attract a large number of customers and make inroads in the customer base of LIC.

Gupta et al (2007) have stated that the potential of the Indian insurance market is huge and the entry of private players will cater to the growing number of customers without jeopardising any individual player.

Faiz Abdullah (2008)has stated that the opening up of the industry to private and foreign players has resulted in wider product choice, computerization of service to accommodate a growing market and introduction of global standards in business. However, there existed the challenges of capital adequacy, solvency margin, cap on foreign direct investment, financial efficiency, infrastructure development and integration of solutions. 
Rao and Madhavi (2008) have argued that there the scene in the insurance sector is a healthy one now with competition from private players drive the industry to better service and better product range much to the benefits of the end user.

Ayem Peruman (2010) has noted that the scene in the industry has been changing rapidly bringing new opportunities and challenges. The challenges that face the industry, he observes, are ever-changing customer needs, structural limitations and market volatility.

Shende and Nilakant Rao (2010) have attributed the entry of private and foreign players with the erosion of the LIC's market and the end of its market monopoly. The Indian Insurance market has grown four folds since liberalization and hitherto unexplored market is now coming under the domain of private players.

Mohammad Amin Mir (2010) has studied and analyzed the pros and cons of the proposed increase of FDI from $26 \%$ to $49 \%$ and has identified why it is welcomed by private players: it helps in raising the capital base and maintain adequate solvency margin while bearing the escalated initial operation costs.

\section{CONCEPTUAL FRAMEWORK}

A conceptual framework was designed and developed to measure the attitude of Chennai based people toward the increase in FDI from $26 \%$ to $49 \%$ in the insurance sector. Based on the review of literature and expert opinions on the issues four factors emerged as being directly impacted by the increase. They are: impact on economy, impact on service to customers, general benefits and impact on business/market themselves.

\section{A. Impact on Economy:}

This variable measures the extent to which the increase in FDI impacts the economy of the city or the country.

\section{B. Impact on Service to Customers:}

This variable measures the impact of increase in FDI on the service to the city-based customers of insurance companies.

\section{General Benefits}

This variable measures the level of perceived benefit of FDI in insurance

\section{Impact on Insurance Business/Market}

This variable aims to measure the likely impact of rise in FDI cap in insurance on the insurance business in major cities in India in which Chennai is representative sample. 


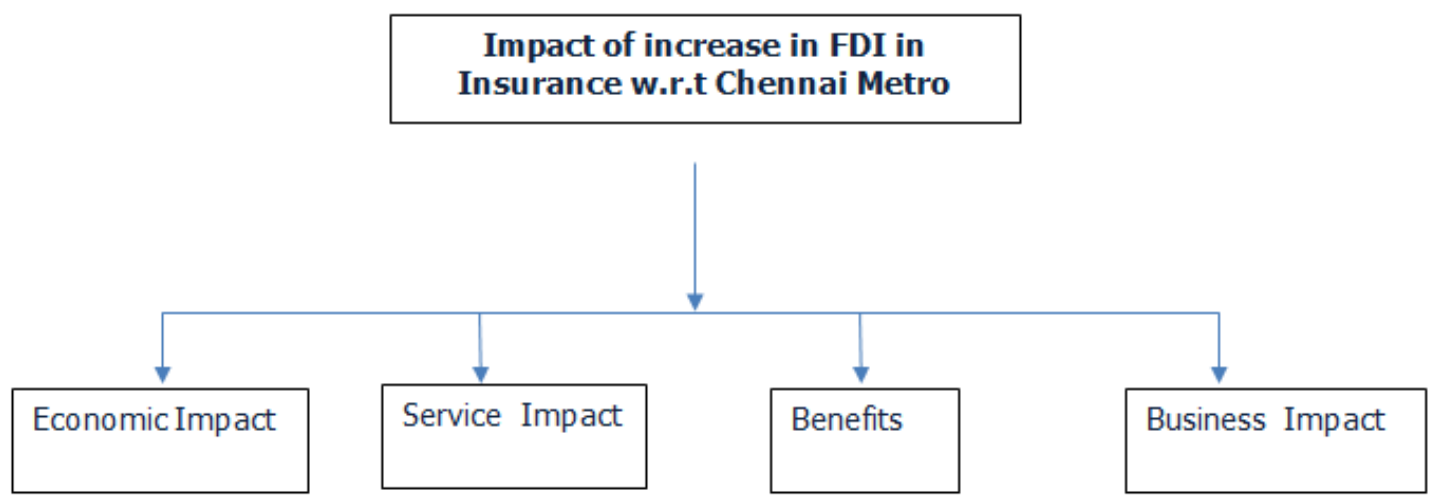

Figure 1: Conceptual Framework of the Study.

\section{RESEARCH METHODOLOGY}

\subsection{SAMPLE AND RESEARCH SETTING}

This study was conducted on the customers and agents of insurance companies in Chennai, a metropolis in the state of Tamil Nadu in India. A sample group of 200 customers and agents were interviewed at their places of work or residence. Each member was interviewed separately and individually for this study. Out the 200 members of the sample group, 175 completed the questionnaire in all details thus yielding a response rate of $87 \%$. Non-probabilistic convenience sampling technique was employed in choosing the sample.

\subsection{RESEARCH INSTRUMENT}

A special instrument with 17 items was designed and developed specifically for the current study. The instrument (a questionnaire) was validated by a team of experts comprising two professors for universities of repute and two senior managers/executives of well-known insurance companies. The scale was developed based on a five-point Likert scale ranging from "strongly disagree" (1) to "strongly agree" (5). The participants of the study were asked to indicate their degree of agreement with each item.

\subsection{STATISTICAL TOOLS}

The collected and collated data were analysed using the software package SPSS 21.0. The statistical analysis included Descriptive Statistics, Reliability Analysis, Exploratory Factor Analysis using Principal Component method with Varimax Rotation and Correlation Analysis.

\subsection{DEMOGRAPHIC DETAILS OF THE STUDY}

Table 1 shows the demographic details of the members of the sample group. It can be observed that most respondents were Chennai based customers $(68 \%)$ while agents constituted a smaller portion at $32 \%$. The male/female ratio of the members of the sample study stands at $83 \% / 17 \%$. About $80 \%$ of the group was married, $57 \%$ of the members held a degree from a university. 
While most were employees of private companies, a sizeable portion of the group was selfemployed.

Table 1: Demographic Characteristics of Sample Customers. $(\mathrm{n}=175)$

\begin{tabular}{|c|c|c|}
\hline \multicolumn{2}{|l|}{ Demographics } & Number/Percentage \\
\hline \multirow{2}{*}{ Status } & Customer & $119(68 \%)$ \\
\hline & Agent & $56(32 \%)$ \\
\hline \multirow{2}{*}{ Gender } & Make & $145(83 \%)$ \\
\hline & Female & $30(17 \%)$ \\
\hline \multirow{2}{*}{ Marital Status } & Married & $140(80 \%)$ \\
\hline & Unmarried & $35(20 \%)$ \\
\hline \multirow{3}{*}{ Age } & Below 30 & $35(20 \%)$ \\
\hline & $31-40$ & $72(41 \%)$ \\
\hline & Above 40 & $68(39 \%)$ \\
\hline \multirow{3}{*}{ Qulaification } & UnderGraduate & $17(10 \%)$ \\
\hline & Graduate & $100(57 \%)$ \\
\hline & Post Graduate & $58(33 \%)$ \\
\hline \multirow{3}{*}{ Employment } & Private Sector & $102(58 \%)$ \\
\hline & Public Sector & $32(18 \%)$ \\
\hline & Self Employed & $41(24 \%)$ \\
\hline
\end{tabular}

\subsection{RELIABILITY ANALYSIS}

Croanbach's Alpha Statistics was employed to test the reliability of the scale developed for the study. The alpha value for the scale was estimated at 0.856 which is well above the cut-off value of 0.70, and hence deemed acceptable (Hair et al. 2010)

\subsection{DESCRIPTIVE STATISTICS}

The descriptive statistics which indicates the average values of the factors of the scale was obtained and is presented here in Table 2. An analysis of the results show that the Chennai based respondents showed a higher degree of acceptance of the proposed increase in FDI and that the perceived impact of such an increase was favourable in all the four counts: service, benefits, economy and overall impact.

Table 2: Descriptive Statistics

\begin{tabular}{|l|l|l|}
\hline Factors & Mean & SD \\
\hline Impact On Economy & 3.3 & 0.73 \\
\hline Impact On Service & 3.7 & 0.46 \\
\hline Overall Benefits & 3.2 & 0.94 \\
\hline Impact On Insurance Business & 3.3 & 0.65 \\
\hline
\end{tabular}




\section{7.t-TEST RESULTS}

An independent sample t-test was conducted to test measure the significance of difference in the mean rating between customers and agents in their perception towards the proposed increase in FDI in insurance. The results of the t-test as shown in Table 2 indicates that there is significant difference in the mean rating between customers and agents for all the factors. The level of significance was 0.001 level for all the cases. Customers of the study viewed that the rise in FDI cap will positively impact the services and more product options will be available to the customers.

Table 3: t-test to test the level of significant differences in the mean rating between customers and agents.

\begin{tabular}{|c|c|c|c|c|c|c|}
\hline Factor & Status & $\mathbf{N}$ & Mean & SD & t-value & p-value \\
\hline \multirow{2}{*}{$\begin{array}{l}\text { Economical } \\
\text { Impact }\end{array}$} & Customer & 119 & 3.5252 & 0.38 & \multirow{2}{*}{$6.5^{* *}$} & \multirow{2}{*}{0.000} \\
\hline & Agent & 56 & 2.7680 & 0.77 & & \\
\hline \multirow{2}{*}{ Service Impact } & Customer & 119 & 3.9972 & 0.44 & \multirow{2}{*}{$4.7 * *$} & \multirow{2}{*}{0.000} \\
\hline & Agent & 56 & 3.3100 & 0.98 & & \\
\hline \multirow{2}{*}{ Benefits } & Customer & 119 & 3.3047 & 0.44 & \multirow{2}{*}{$2.9 * *$} & \multirow{2}{*}{0.004} \\
\hline & Agent & 56 & 3.0380 & 0.55 & & \\
\hline \multirow{2}{*}{ Market Impact } & Customer & 119 & 3.1467 & 0.76 & \multirow{2}{*}{$4.1^{* *}$} & \multirow{2}{*}{0.000} \\
\hline & Agent & 56 & 3.6540 & 0.59 & & \\
\hline
\end{tabular}

** - Significant at $1 \%$ level

\section{DISCUSSION}

An analysis of the data and statistical indicators show that the Chennai-based respondents welcomed the proposed increase in FDI and perceived that the proposed increase could usher in healthy competition and thus bring about a favourable change in terms of quality of service, range of products and options, economic growth and opportunities and an overall positive impact.

\section{CONCLUSION}

This study represents a small step to gauge the impact of the proposed increase in the FDI in insurance sector. The group of respondents, though small, represented the insurance sector in a micro-level. However, the study has been confined to urban-based respondents and has not taken into account the upcountry market for insurance products. However, this study is a part of a major study in developing standardized parameters to assess the impact of the proposed increase in FDI in insurance sector on a macro level. 


\section{REFERENCES}

[1] Ayem Perumal, S. (2010). "Impact of Economic Globalization and Consumer Expectations in Life Insurance”, Southern Economist, $p .8$.

[2] Bansal, A. (2005). Insurance Sector: Is privatization on the right track. Management Accountant-Calcutta, 40(12), 931.

[3] Faiz Abdullah (2008). "Issues and Challenges of Privatisation of Insurance Sector", Ph.D. Thesis submitted to the Department of Commerce, Aligarh Muslim University, Aligarh.

[4] Gupta, S. K., Aggarwal, N., \& Gupta, N. (2004). Financial Institutions and Markets.

[5] Mohmed Amin Mir, "Growth Pattern of Foreign Direct Investment in India since Liberalisation: A Case Study of Indian Insurance Sector”, Ph.D Thesis submitted to the Department of Commerce, Aligarh Muslim University, Aligarh, 2010.

[6] Murthy, G.R.K. (2004). "Foreign Direct Investment in Insurance: That's What the Economy Needs”, Insurance Chronicle, The ICFAI University Press, pp.61-66.

[7] Nirjhar Majumdir (2005). "Achievement of Indian Insurers in covering Uninsured Sectors during last 5 Years", The Journal of Insurance Institute of India, p.64.

[8] Pooja Bhalla and Gangandeep Kaur (2007). "Private Players and Life Insurance Industry”, Indian Journal of Finance, p.34.

[9] Rao, N.S.B. and Madhavi, C. (2007). "An Overview of the Private Insurance Company", In Nalini Prava Tripathy and Prabir Pal (Eds.), "Insurance Theory and Practice", Prentice Hall of India Private Limited, New Delhi, pp.104-115.

[10] Sam Ghosh (2005). "Changing Horizon of Insurance Sector," The Chartered Accountant, pp.1528-1531.

[11] Sayulu. K. and Sardar, G. (2005). "Customer Satisfaction with regard to LIC Policies", The Indian Journal of Commerce, Vol.58, No.2, p.91.

[12] Shendey, B.K. and Neelkant Rao, "Trends in Insurance Industry in India since 21st Century”, Southern Economist, December 15, 2010, p.24.

[13] Vijayakumar, A. (2004). Globalization of Indian insurance sector-Issues and Challenges. MANAGEMENT ACCOUNTANT-CALCUTTA-, 39(3), 195-198.

[14] Krishna Kumar and Kannan, R.. (2005). "LIC-Countering Threat from Private Player. 